\title{
A Bank Lending Channel that is working via Housing or via Consumer Loans? Evidence from Europe
}

\author{
Stefanos Papadamou ${ }^{1+}$, Vaggelis Arvanitis ${ }^{2}$ and Costas Siriopoulos ${ }^{3}$
}

\begin{abstract}
This paper, tests the bank lending channel of monetary policy transmission mechanism in a series of European countries since the Euro currency circulation. By disaggregating bank loans to households for consumer, housing and other purposes over the period 2003:Q1 to 2012:Q4, we try to shed light to any hidden dynamics by aggregate data. An unrestricted VAR model and impulse response analysis provide empirical evidence of an active bank lending channel working via housing loans for the majority of countries studied (Germany, France, Belgium, Italy, Spain, Sweden and UK). Additionally, there is evidence of a transmission mechanism proceed through consumer credit in Austria, Belgium and Netherlands. Moreover our results reveal that monetary transmission to housing loans proceeds quickly in Germany, Spain, Sweden and UK compared to the others. However in Belgium, Germany and UK, consumer credits reduction also amplifies the initial shock on GDP and on inflation produced by a tightening monetary policy. Finally, banks' lending behaviour varies significantly according to the purposes of household loans. In Belgium, Sweden and UK, housing loans reductions coexist with increase of loans for consumption and other reasons, implying that the former is driven by supply forces while the latter by demand forces.
\end{abstract}

JEL classification numbers: E40 E52 G21

Keywords: Monetary policy, bank lending, Transmission mechanism VAR models

\section{Introduction}

In early 1990s a large body of literature has examined the process of monetary transmission in general and the credit channels in particular (for an overview see Gertler and Gilchrist, 1993a; Ramey, 1993; Bernanke and Gertler, 1995). According to the

\footnotetext{
${ }^{1}$ Dept. of Economics, University of Thessaly, Volos, Greece

+ Corresponding author.E-mail: stpapada@uth.gr

${ }^{2}$ Dept. of Economics, University of Thessaly, Volos, Greece

${ }^{3}$ College of Business, Zayed University, U.A.E
}

Article Info: Received: September 10, 2014. Revised : November 30, 2014

Published online : December 30, 2014 
traditional 'money view' theory ${ }^{4}$, a monetary tightening (such as an increase in interest rates) drain the deposits and bank reserves. The basic idea of this money view is that bank assets are perfect substitutes. As a result of a monetary tightening, via an increase in interest rates, money demand is decreased due to higher cost of capital. Banks in order to reach the equilibrium in their portfolio reduce their assets. Consequently, real economy is affected through the reduction in investment, consumption and income.

In contrast to the 'money view', bank loans and bond issues are considered as imperfect substitutes. Bernanke and Blinder (1988) assume that problems are raised if bank assets are imperfect substitutes. Borrowers with no ready or limited access to non-bank sources (open capital market or the commercial paper market) depend exclusively on bank credit for external funding. The lending channel works if the reduction in credit is larger than the reduction in other forms of financing from capital market. 'Credit view' has traditionally separated into two channels: the balance sheet channel and the bank lending channel (Bernanke and Gertler, 1995) ${ }^{5}$. The balance sheet channel, generally, exceeds the role of external finance premium emanated from informational frictions, depending on the financial position of borrowers. Identification problems stretched out in separating the two channels. Bank lending channel emphasizes on bank dependent borrowers' decreased spending, due to a decrease in loans supply derived from informational asymmetries. The existence of this lending channel depends on two important conditions. First, monetary authorities should be capable of affecting the supply of bank loans, and second there should be no perfect substitutes to bank loans for at least some types of borrowers. After a monetary constrain, banks do not fully offset the reduction in deposits simply by substituting wholesale market funding for lost deposit funding and thus precipitating a shift of credit supply. The latter phenomenon it is most commonly appeared in financial crisis periods (e.g. in the 2007 financial crisis that is transformed to debt crisis in Europe recently).

Although the balance sheet channel is especially applicable to households as small borrowers, the attention paid to the role of households' balance sheets in monetary policy transmission is limited compared to the balance sheet of firms ${ }^{6}$. Moreover, special attention should be paid on household loans given the fact that the necessary condition for the existence of a bank lending channel - the specialness of bank credit- holds for households since they lack access to other forms of credit than bank loans.

While first studies investigating empirically bank lending channel assumed lenders heterogeneity - small capitalized illiquid banks versus large capitalized banks - (see for instance Kashyap and Stein, 2000), recently there is few papers assuming heterogeneity among borrowers in order to investigate any evidence for an active bank lending channel (see Escriva and Haldane, 1994; Dale and Haldane, 1995;Garretsen and Swank, 1998, 2003; Kuppers, 2001;Papadamou and Siriopoulos, 2012). The latter studies are mainly focused on a single country and disaggregate total loans to two main categories household and corporate loans.Among others, Buttiglione and Ferri (1994), Guender and Moersch (1997), Dedola and Lippi (2005), argue that disaggregate data are better than aggregate, giving more precise information and depictions of the economy.

\footnotetext{
${ }^{4}$ Based on IS-LM model.

${ }^{5}$ Bernanke and Gertler (1995), argue that credit channel is not an independent channel compared with money channel, but a bulk of macroeconomic variables who amplifies the interest rate effects. ${ }^{6}$ The first effort in aggregate Euro area data concerning balance sheet channel by investigating external finance premium for firms is made by de Bondt (2004).
} 
In accordance with this argument for disaggregation, in general, this paper investigates whether disaggregation of household loans to sub-categories based on their purposes (for consumption, for housing, for other purposes) may provide helpful information about monetary transmission in a set of European countries. More specifically, if microcomponents of these loans follow different behaviour aggregation may hide any evidence of an active bank lending channel. This study contributes to existing literature by investigating households' heterogeneity in a single policy regime that coincides with the Euro currency birth. Moreover, we tried to investigate and answer the following question; whether bank lending channel in cases that is active in some countries works via housing loans, consumer credit, other type of loans or via all types of loans. Any possible amplification of the initial interest rate shock on inflation and gross domestic product, via credit channel is investigated across different countries by leading us to useful comparisons.

On the one hand, household loans for housing purposes play an important role in the economy, in general, as if they assist consumers to possess real estate assets via housing investments. Additionally, housing market influences the consumption and investment and according to Iacoviello and Minetti (2008) 'there are some reasons to expect that housing market is exposed to credit channel'. Giuliodori (2005) mentioned the role of housing prices in nine European countries without providing evidence of real estate bank lending transmission mechanism.Also, Elbourne (2008) suggested that house price shocks increase consumption, the price level and interest rates and that house price movements can explain about one-seventh of the fall in consumption following an interest rate shock. Moreover, Iacovielo (2004) argued that the nominal interest rate is clearly important in determining the initial affordability of a mortgage for a given house value. Moving one step forward, Papadamou and Siriopoulos (2012) reveal the role of mortgage loans in bank lending channel in Sweden, by investigating banks' loan portfolios.

On the other hand, consumer credit can have significant effect in countries where economy is mainly based on consumption growth. Therefore is worth investigating the role that household loans for consumption play in the monetary transmission mechanism. In order to grasp the existence of such a transmission mechanism through housing and consumer loans, we adopt (while the majority of the literature) impulse response function analysis of an estimated vector autoregressive model (VAR).

The rest of the paper is organized as follows. Section II provides the literature review. Section III presents data and methodology. Discussion of empirical results occurs on section IV, while section V concludes the paper.

\section{Literature Review}

In the last two decades, there have been several empirical studies providing evidence of the existence of bank lending channel, first in the U.S. and latter in the European Union. The existence of a transmission mechanism through bank credit first has been pointed out by Bernanke and Blinder (1988) triggering a vast of researches on that field of monetary policy and interest rate changes, where the effectiveness of this mechanism vary between banks with different characteristics. According to the literature, banking sector plays a major role on the process of that mechanism (Bernanke, 1993; Gertler and Gilchrist, 1993b; Kashyap and Stein, 1995). Additionally, after a monetary tightening policy, less 
liquid banks could not substitute their loan portfolio even after a decrease on their cash and securities(Stein, 1998; Kashyap and Stein, 2000; Kashyap et al., 2002). Facing the same result, Peek and Rosengren (1995), and Kishan and Opiela (2000), argue that poorly capitalized banks rely on monetary policy shocks more than banks with high capitalization. These studies report the differences in the effectiveness of bank lending channel referring to the U.S.A significant part of them have been done by using VAR models that include usually the policy rate, price index, a measure of real economic activity but also other variables ${ }^{7}$.

Moreover, for the G-7 countries, Gerlach and Smets (1995) applied a VAR model combined with both short-run and long-run restriction and included only three variables (output, price level and interest rate), tried to find out the existence of a transmission mechanism, stressing out the differences between the methodologies.

Literature on European Union was not so far extended (see among the first studies Dale and Haldane, 1995; Tsatsaronis, 1995). But, after the European monetary integration ${ }^{8}$ a bulk of studies tried to shed light on the existence of a bank lending channel in countries with heterogeneity in their financial structure (see among others, Cecchetti, 1999; Ehrmann et al., 2001; Altunbas et al., 2002; Gambacorta, 2005). Due to heterogeneity and other structural and financial differences between European countries, there are not clear results on the effect of interest rate (Mojon, 2000; De Bondt et al., 2003), prohibiting the EMU to exercise the monetary policy efficiently (Kashyap and Stein, 1997; Ramaswamy and Slok, 1998). All these studies, by using information on transmission mechanism before Euro adoption, provide implication about the effectiveness of a common monetary policy effects on the European countries. In contrast, our study, after ten years of the common currency, investigates the realized transmission mechanisms in European continent by paying particular attention on economic expectations proxied by Economic Sentiment Indicator.

In the pre-EMU period Mojon and Peersman (2001) tested the effect of monetary policy in the euro area countries divided them into three categories (regime-like) depending on their monetary integration with Germany playing a key role, resulting in the similarities occur in the effects of monetary policy shocks in all examined countries. Monetary transmission mechanism in European countries has been under examination by Escriva and Haldane (1994), Dale and Haldane (1995) and Kuppers (2001) in U.K., Spain and Germany, respectively. Buttigliore and Ferri (1994) and Guender and Moersch (1997) for Italy and Germany exposed the misleading results of aggregate data sets. Additionally, Favero et al. (1999) using microeconomic bank data found that in four European countries (France, Germany, Italy, Spain) credit channel is an important transmission mechanism after a monetary tightening. Peersman (2004) estimated a VAR model among seven countries of the Euro zone, after a monetary policy shock, drawing the conclusion that there are uniform effects across countries. Finally, estimating the impulse responses of thirteen European countries after a monetary policy shock, Ehrmann (2000) found out that most European countries are relatively homogenous, apart from U.K.

Dedola and Lippi (2005), argue that there is an active bank lending channel in Germany applying a series of models(VAR, SVAR and VECM). Reinforcing the previous results, Angeloniet al. (2002), analyzed the existence of a bank lending channel in the euro zone,

\footnotetext{
${ }^{7}$ For more information see Christiano et al. (1999).

${ }^{8}$ For an extended analysis of the monetary policy in the Euro area and the ECB reactions between 1999-2006 see Fischer et al. (2009).
} 
using two different econometric approaches (non-structural and structural models), reaching the conclusion that bank lending channel, through investment, is powerful in Germany and Italy ${ }^{9}$.

Recently a series of papers indicates the importance of central bank characteristics such as transparency (Papadamou, 2013; Papadamou, Sidiropoulos, Spyromitros, 2014a) and credibility (Papadamou, Sidiropoulos, Spyromitros, 2014b) on the effectiveness of monetary policy implementation.

Concerning studies focusing on housing market, Yao and Zhang (2005) assert that housing differs from other financial assets and loans because housing serves a dual purpose. It is both a durable consumption good from which the owner derives utility and also an investment vehicle that allow the investors to hold home equities.

Several empirical studies support the importance of a credit channel in housing investment and consumption (Muellbauer and Murphy 1997). In their point of view, collateral effects, due to a restriction on consumers borrowing rise, change housing prices. McCarthy and Peach (2002) argue that an increase in interest rates leads to a decrease in house prices. Furthermore, Aoki et al. (2004) pointed out that houses provide not only housing services, but acting as collateral decrease borrowing costs. As a result, monetary shocks affect housing investment, house prices and consumption. Additionally, they exceed the role of house prices on consumption through household borrowing. Moreover, Den Haan et al. (2007) argue that a monetary tightening has significant effect (decrease) on consumption and housing loans along with an increase on commercial and investment loans. Iacoviello and Minetti (2008) analyzed the credit channel focusing on housing market, tested the presence of a bank lending channel in four European housing markets (Finland, Germany, Norway, UK) with different institutional frameworks, found a clearcut relationship between bank lending channel and efficiency in housing funding. They, also, highlighted the important role of housing in aggregate economy (see also Maclennan et al., 1998; Mishkin, 2001; Leung, 2004; Warnock and Warnock, 2008). Apart from efficiency, Giuliodori (2005) provide to the literature a link between house and residential prices and aggregate demand with interest rate shocks for nine European countries, exceeding the importance of competitiveness. In the case of the Netherlands, Garretsen and Swank (2003) found out that after a tightening monetary policy, there is an instant fall of household loans, but not following by a decrease in consumer expenditure, stressing out the importance of heterogeneity among borrowers. Because of the above, they assume that the bank lending channel in the Netherlands is not active. Analyzing the housing sector (among others) in France and Germany, Barran et al. (2003) applying a VAR model, pointed out the heterogeneity among the countries with Germany's housing market being more sensitive, after a monetary tightening, than in France. Koufmann and Valderrama (2008), applied a MS-VAR model in sectoral credit aggregates (loans to households and loans to non-financial corporation) in two countries with different financial systems (Germany-bank based and UK-market based), found evidence for different reactions of lending to every shock.

\footnotetext{
${ }^{9}$ For further information in bank lending channel across euro zone and European countries using VAR and SVAR models, see Gerlach and Smets (1995), Kieler and Saarenheimo (1998), Ehrmann (2000), Altavilla (2000).
} 


\section{Data and Methodology}

In our study, quarterly data about inflation, gross domestic product, central bank rate, household loans and Economic Sentiment in dicatorare collected from International Financial Statistics (IMF) and European Central Bank (ECB) databases respectively. Our sample period covered was from 2003Q1 to 2012Q4 and determined based on the availability of household loans across European countries. Seven countries from Eurozone (Austria, Belgium, Netherlands, France, Germany, Italy, Spain) and two from North Europe, not belonging in Eurozone (UK and Sweden), consist our sample countries.

Following the vast majority of the existing literature of the monetary transmission mechanism, a multivariate Vector Autoregressive (VAR) model is implemented. VAR models can trace out the responses of the endogenous variables due to a shock on a series of financial variables. Additionally, these types of models can adapt the dynamic effects of a shock; functioning as a proxy of the true data-generating process (Papadamou and Siriopoulos, 2012). Additionally, the VAR approach recognizes the simultaneous relation between macroeconomic developments. Specifically, it describes the dependence of monetary policy on economic variables (the policy reaction function) and vice versa (Morsink and Bayoumi, 2001).

In order to identify monetary policy shocks, we estimate a number of VAR models. Identification of the monetary policy shock is the main problem during the evaluation of the effects of that policy (Barran et al., 2003). Assuming that the economies of the countries examined, for the existence of an operational mechanism through housing and credit loans, in our study can be described by a linear stochastic and dynamic model. A simple model of three variables can be presenting in the following form ${ }^{10}$ :

$Y_{t}=B_{0} Y_{t}+B_{1} Y_{t-1}+\ldots+B_{p} Y_{t-p}+u_{t}$

where $Y_{t}^{\prime}=\left[X_{1 \mathrm{t}}^{\prime}, r_{t}, X_{2 \mathrm{t}}^{\prime}\right], X_{1 \mathrm{t}}$ is a $\left(k_{1} \times 1\right)$ vector with items linked to the set of information of the central bank, $r_{t}$ is the central bank interest rate, $X_{2 \mathrm{t}}$ is a $\left(k_{2} \times 1\right)$ vector with items not in the information set of central bank, and $u_{t}$ is a $(k \times 1)$ vector of residual terms, with $k=k_{1}+1+k_{2}$. The error term is identically and independently distributed following a Gaussian distribution $\mathrm{u}_{\mathrm{t}} \sim$ iid $\mathrm{Np}(0, \Omega)$, where $\Omega$ denotes the variance-covariance matrix of the error. The relationship between the reduced form error term $\varepsilon_{t}$ and the structural shock to the economy, $\varepsilon_{t}$, is given by the equation:

$u_{t}=\bar{A} \varepsilon_{t}$,

where $\bar{A}$ is a $(k \times k)$ matrix of coefficients and $\varepsilon_{t}$ is a $(k \times 1)$ vector of uncorrelated shocks. According to Christiano et al. (1999), the effects of a monetary policy shock has the following block-triangular form:

\footnotetext{
${ }^{10}$ This is a solution used in the works of Sims $(1980,1992)$. For further information see Bernanke (1986), Bernanke and Blinder (1992), Christiano and Eichenbaum (1994) among others.
} 


$$
\bar{A}=\left[\begin{array}{lll}
\bar{A}_{11} & 0_{k_{1 \times 1}} & 0_{k 1 \times k 2} \\
\bar{A}_{21} & \bar{A}_{22} & 0_{1 \times k 2} \\
\bar{A}_{31} & \bar{A}_{32} & \bar{A}_{33}
\end{array}\right],
$$

Where $\bar{A}_{11}$ is a $\left(k_{1} \times k_{1}\right)$ matrix, $\bar{A}_{21}$ a $\left(1 \times k_{1}\right)$ matrix, $\bar{A}_{31}$ a $\left(k_{2} \times k_{1}\right)$ matrix, $\bar{A}_{22}$ a $(1 \times 1)$ matrix and $\bar{A}_{32}$ a $\left(k_{2} \times 1\right), \bar{A}_{33}\left(k_{2} \times k_{2}\right)$ matrices. 0ixjis a $(i \times j)$ matrix with zero items.

Since our purpose is to analyze the existence of a transmission mechanism operating through the disaggregate data of loans to households and consumer credit, after a monetary policy shock, first we employ an aggregate VAR model for each economy and in a second step, after disaggregating the data, we try to shed light on the loans portfolio that significantly affects the aggregate economy. The model consists of five variables common to all countries. (Economic Sentiment Indicator-ESI, GDP, Inflation ${ }^{11}$, Central Bank Rate, Households' Loans for a specific purpose). Following Brissimis and Maggin as (2006), our basic model is augmented with the composite leading indicator (ESI) of near term developments in economic activity; a forward looking variable in order to control for the information set of the central banks. For member-state countries of the European Monetary Union we treat the European Central Bank interest rate (ECB rate) as instrument for monetary policy shock. For the other countries we use the relevant central bank rate where is provided and the money market rate as a proxy to the central bank interest rate in cases that is not provided.

We should mention at this point of the paper that the inclusion of all different borrowers' variables in one model would exhaust the number of degrees of freedom given our data sample. Hence, as a rule, we adopt the strategy followed, among others, by Garretsen and Swank (2003) and Gertler and Gilchrist (1993b) that estimated VAR models by selecting different type of loans in each model. The first VAR includes the total loans, where the second, the third and the fourth VAR models consist of household loans, consumer credit, and other type of loans respectively.

All series are in natural logarithm apart from interest rates and inflation. In order to capture worldwide effects such as financial crisis in 2007 the Federal Fund rate of USA is included as exogenous variables in the models (similar action has been taken by Weber et al., 2009). Moreover in order to capture recent financial crisis transmitted in all over the world though Lehman Brothers default, a dummy variable taking the value of one from the third quarter of 2008 to the last quarter of 2010 is also included in the models. By treating these variables as exogenous, we allow for a contemporaneous impact of the exogenous on the endogenous variables, but not for a feedback (see also Peersman and Smets, 2003).

Given that all variables are stationary in first differences, we estimate the VAR models in levels, even though Sims et al. (1990) defend that VAR in levels is over-parameterized

\footnotetext{
${ }^{11}$ In case of UK RPIX inflation is used instead of CPI inflation. The former reflects retail prices growth in all items excluding mortgage interest. Because the UK CPI includes mortgage interest payments, CPI inflation is biased upwards following an interest rate increase.
} 
leading to consistent but inefficient estimates. The loss of inefficiency has to be weight against the risk of inconsistency of estimates that occurs when the wrong cointegrating equation restrictions are imposed. Moreover, given the long run neutrality of monetary policy, Favero (2001) argued for estimating VAR in levels when economic interest is related to the short-run period.

\section{Empirical Results}

We start our investigation into a possible bank lending channel by estimating our basic model for every country including the five endogenous variables $[\log (\mathrm{ESI}), \log (\mathrm{GDP})$, Inflation, Central Bank Rate, $\log$ (household loans)] and the two exogenous [US Fed Rate, Dummy related to Lehman Brothers default]. A series of separate VAR models is estimated including different type of household loans every time (total loans, loans for housing purposes, loans for consumption and loans for other reasons).

Table 1 presents the Cholesky impulse response functions of each type of household loans to a monetary policy shock ${ }^{12}$. Each column of the table corresponds to one country. Each line corresponds to a specific VAR model that includes a specific type of household loans $\left(1^{\text {st }}\right.$ line total loans, $2^{\text {nd }}$ line housing loans, $3^{\text {rd }}$ line consumption credit, $4^{\text {th }}$ line loans for other purposes).

It is obvious from Table 1 that banks' lending behavior varies significantly according to the purposes of household loans. More specifically, in Belgium, Germany, Italy and $\mathrm{UK}^{13}$, there is evidence that after a monetary constrain, banks prefer to reduce loan supply for housing purposes, but increase the loans for consumer credit derived possibly from an increase in loan demand. This heterogeneity in the response of household loans to monetary policy shocks can be a first evidence of an active bank lending channel working via housing loans.

However, in other European countries there is evidence of a decrease not only to housing loans, but consumer credit too (France and Spain ${ }^{14}$ ).Moreover, statistically significant reductions to consumer credits but not to other purposes loans for Austria, Belgiumand Netherlands, implying different asset allocation in banks' loan portfolios. For example, in Netherlands consumer credit reacts due to a monetary shock, decreasing the supply of this type of loans by $0.10 \%$ (lower point) after fourquarters. Far from reduction, other loans are gradually increased ground by households' increasing demand for loans and not from banks (due to the monetary restrictions).

\footnotetext{
${ }^{12}$ For economy of space we present only the impulse response function of household loans to monetary policy shocks.

${ }^{13}$ Results of an active bank lending channel in UK are following Huang(2003).

${ }^{14}$ See also Hernando and Pagés (2001) for Spain.
} 
Table 1 Impulse responses of different type of household loans to monetary policy shock

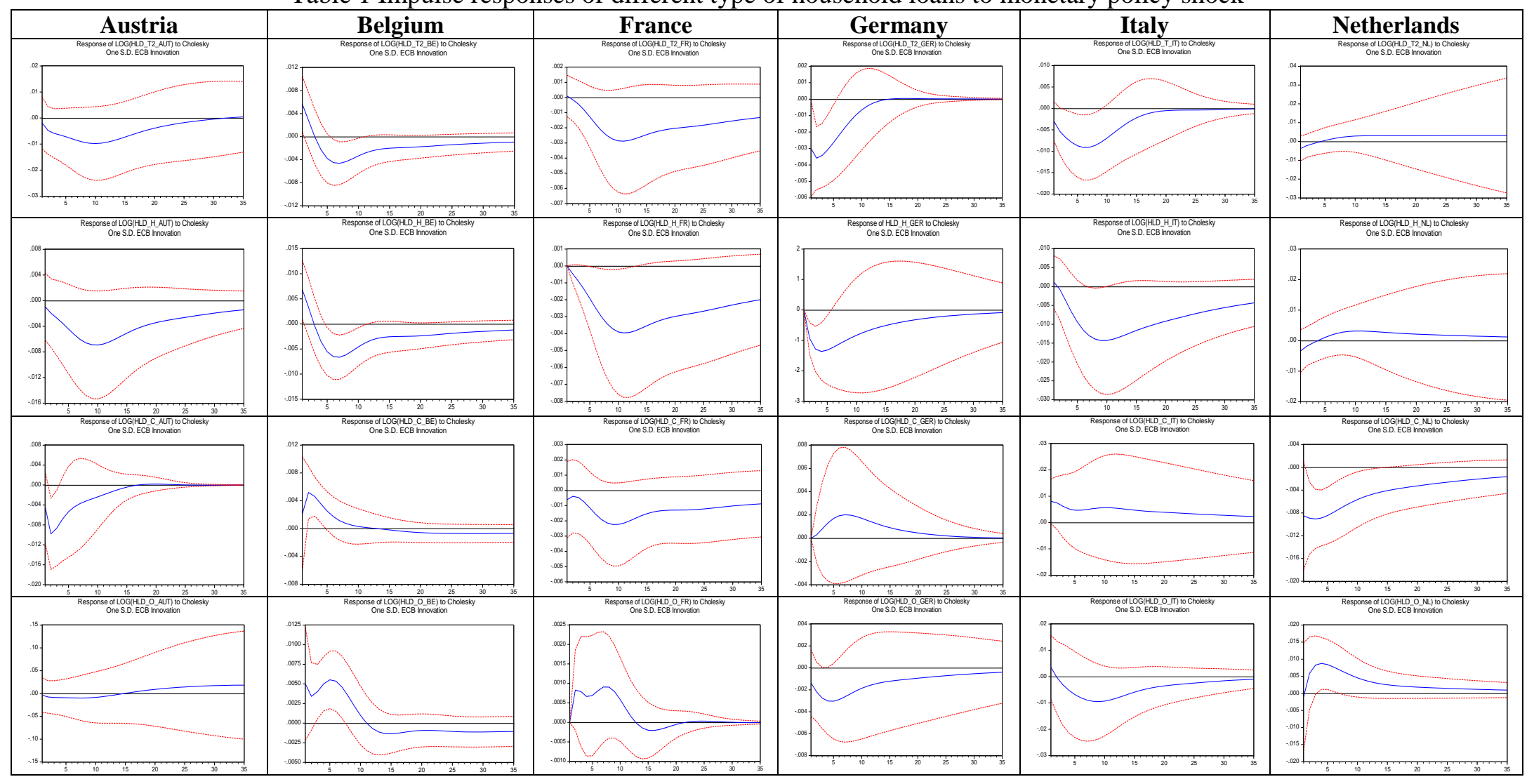




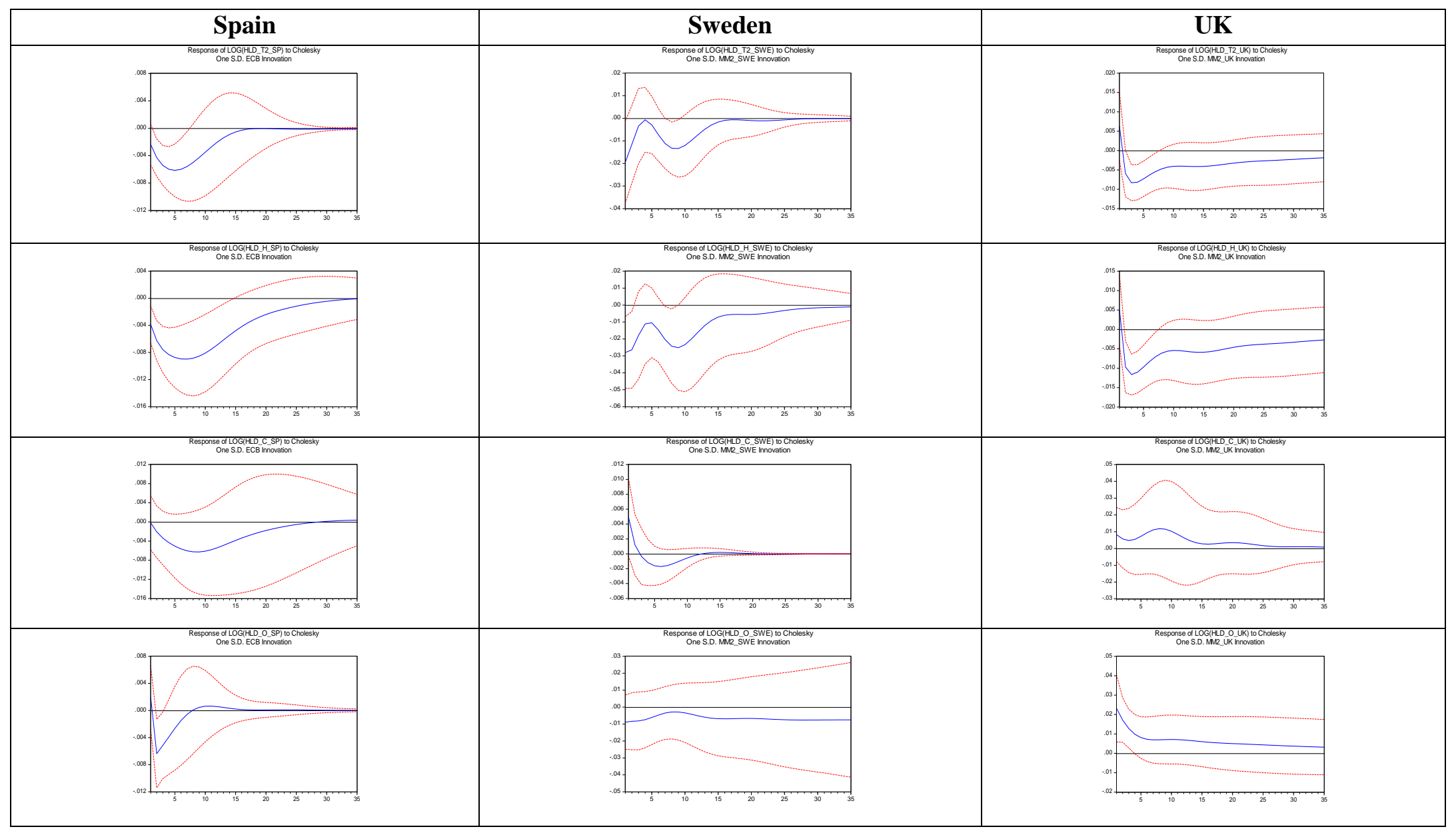


Additionally, in order to provide empirical evidence for the existence of an active bank lending channel, we have to investigate if there is a multiplicative effect of these loans to economic activity and prices. In details, Belgium's housing loans are decreasing significantly; reaching the lower value of approximately $0.10 \%$ after six quarters, after a monetary constrain policy, with economic activity and inflation significantly, also, decreased, reaching their lower price of $0.02 \%$ and $1 \%$ after eleven and fifteen quarters, respectively. Similar results are provided in the French case, where all variables of the model of housing loans are statistically significant and in accordance with economic theory (economic activity and inflation decrease, following an increase in central banks' interest rate $)^{15}$.

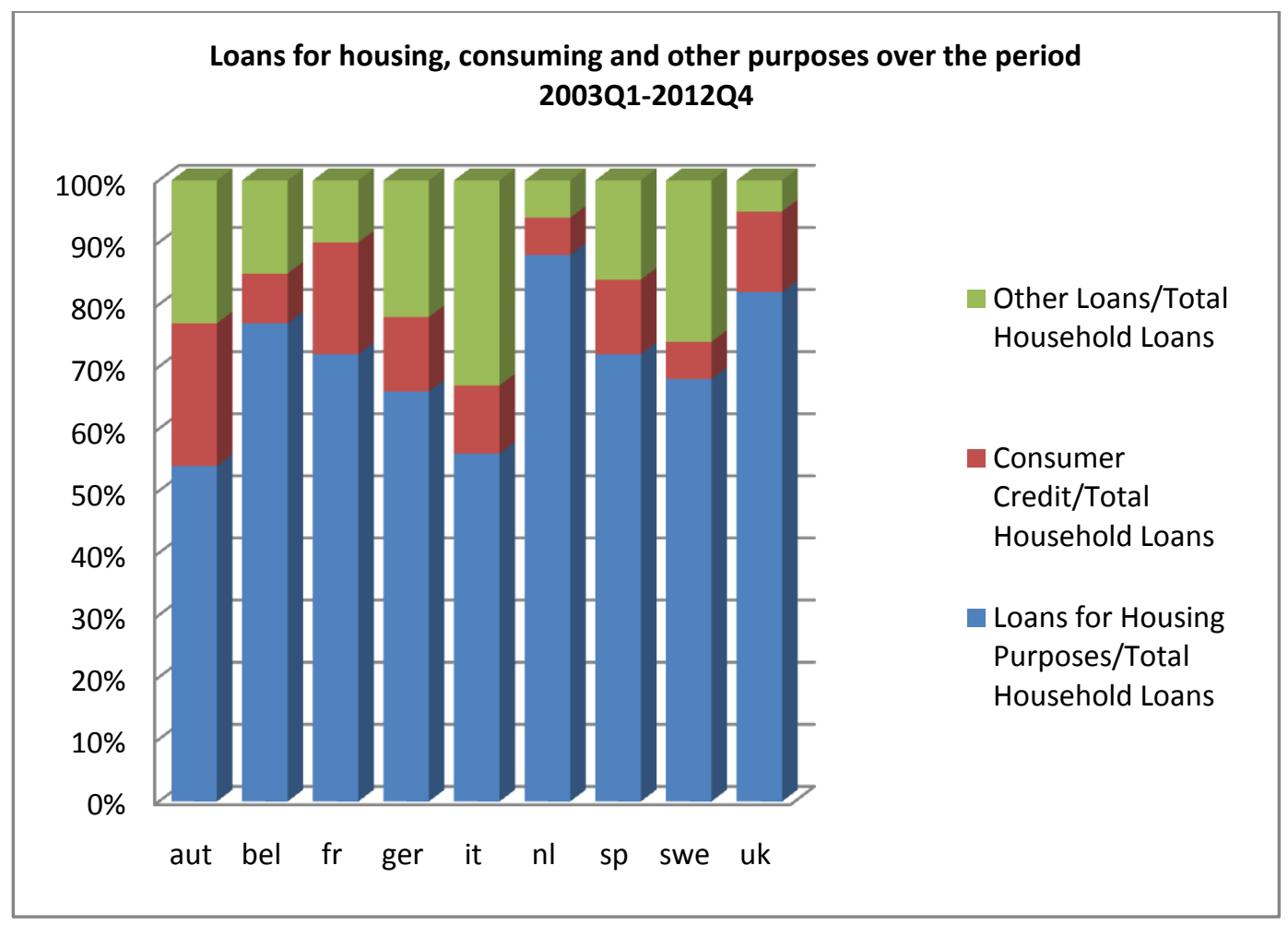

Figure 1: Loans for housing, consuming and other purposes over the period 2003Q12012Q4

Figure 1 presents the bar chart of the three household loans subcategories as a percentage of total household loans (Loans for housing purposes/Total household loans, Consumer credit/ Total household loans, Other loans/ Total household loans). In countries where the percentage of loans for housing purposes is over 50\%- meaning that this category of loans play an important role in bank lending (all the countries included in our research) - we can assume and enhance our first allegation of the importance and the existence of an active bank lending channel working through loans for housing purposes. However, according to

\footnotetext{
${ }^{15}$ Following this analysis, we can depicture the effects of monetary policy shocks in economic activity, inflation and loans for the rest of the countries under examination.
} 
Toolsema (2002), 'because of income and wealth effects in consumption and the possible effect of consumer confidence, the situation in the consumer credit market likely affects the business cycle'. Therefore following this statement our paper investigates any empirical evidence of the existence of a bank lending channel working via consumer credit, also.

In order to shed light on the role of household loans on economic activity and prices, initially, we categorize the countries into two groups according to the type of loans (housing loan or consumer credit) which presents a significant reduction to an interest rate shock. Then, following methodology introduced by Morsink and Bayoumi (2001) each loan type is treated first as endogenous and then as exogenous variable in the VAR models and compare responses of GDP and inflation to monetary policy shocks. The latter procedure (i.e. treat lending variable as exogenous) generates a VAR identical to the former (with identical orthogonalized innovations) except that it effectively blocks off any responses within the VAR model which pass through the lending variable of interest. Table 2 presents the effect of loans on economic activity and inflation respectively, under the two cases described.

Table 2:Treating Housing Loans as Endogenous vs Exogenous variable

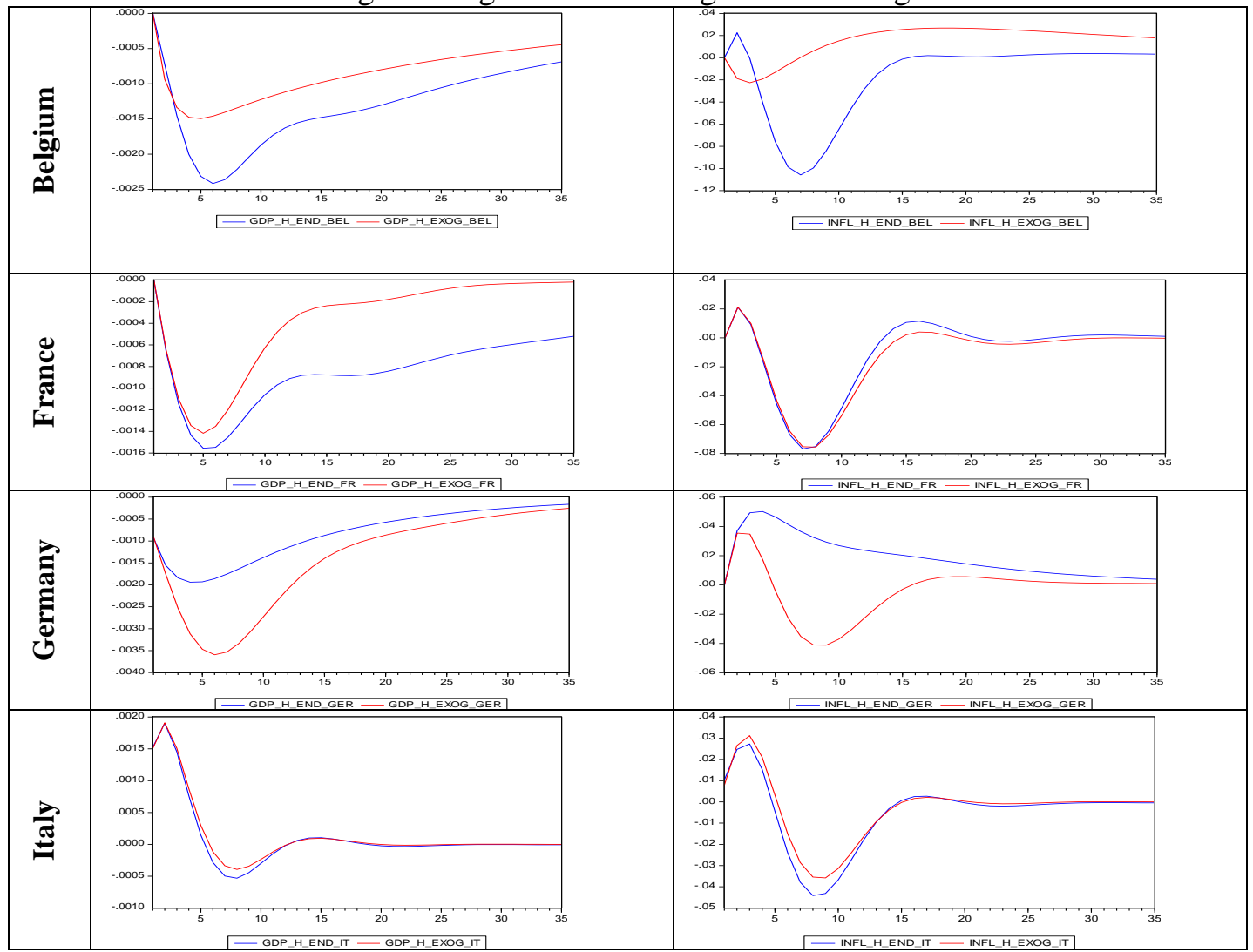




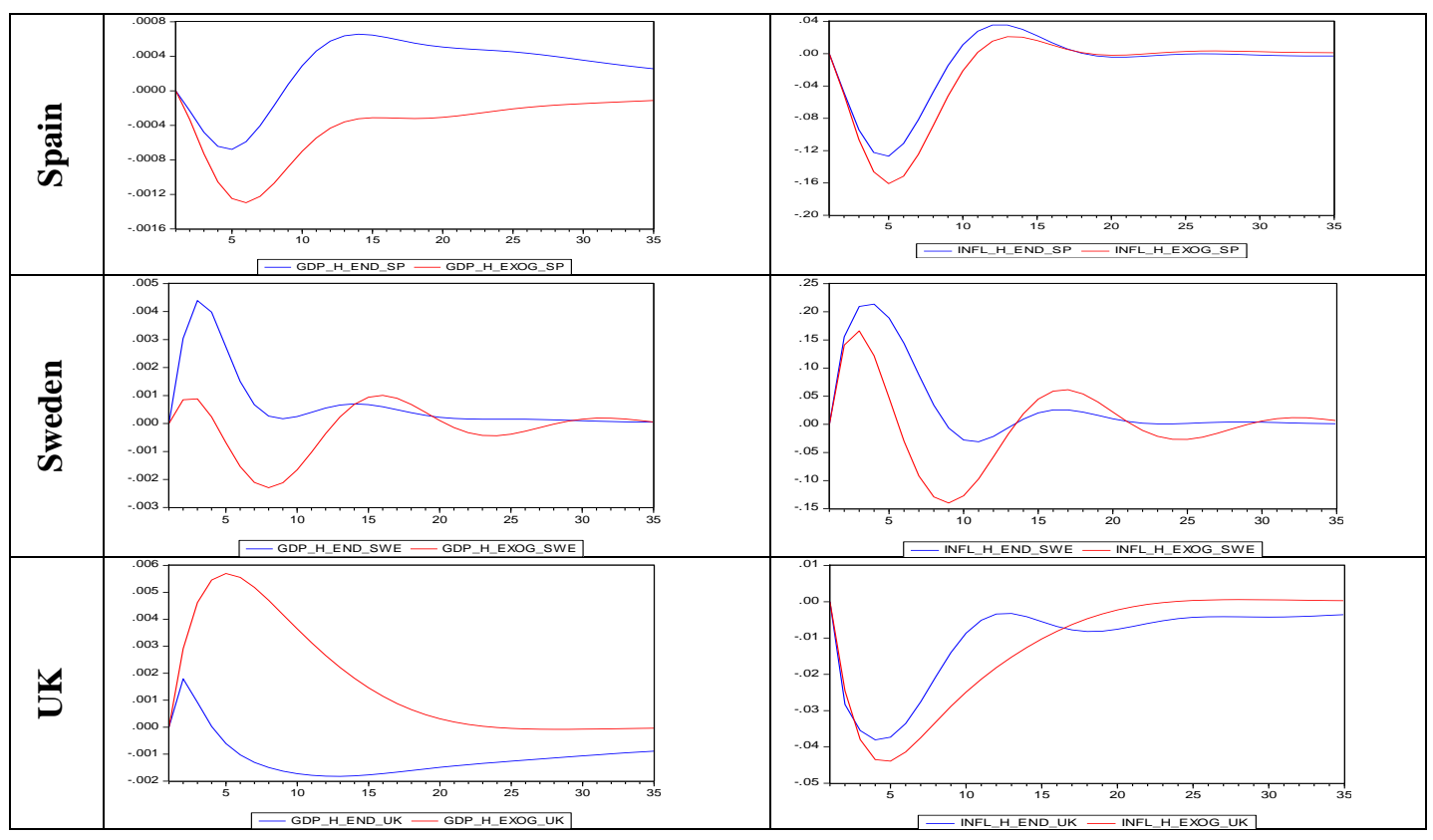

By looking Table 2, we can conclude that exogenizing housing loans sharply dampens the impulse response of GDP to interest rate. In case of Belgium, Germany, Spain, Sweden and UK there is evidence also of a small time lag in the reaction to monetary policy shock. Our results suggests that, after six quarters more than half of the direct impact of a change in the policy rate on GDP comes through household loans for housing reasons. On the one hand, this effect is much stronger in UK and Sweden. The latter result for Sweden is in accordance with previous work by Papadamou and Siriopoulos (2012) that studied lending decisions of commercial banks to housing institutions. On the other hand, the effect is weaker for the case of France and Italy, indicating a smaller role of housing loans in monetary transmission.

By considering the effect of housing loans on the relation between monetary policy shock and inflation, we can see a similar to GDP picture. However, the effect is small in Italy, while do not play any role in case of France after six quarters. Overall we can conclude, that the presence of housing loans affects both economic activity and prices (inflation in our model), confirming our first claim of the existence of an active bank lending channel through housing loans in seven European countries.

As far as consumer lending is concerned, Table 3 affirms the allegation that there is an active bank lending channel in Italy and Netherland working via consumer credit on economic activity. Moreover, by investigation the role of consumer credit on the effect of monetary policy on inflation, it is worth mentioned in the countries above. In these countries consumer lending amplifies the initial effect of monetary policy tightness on inflation. Similar effect but in weaker degree is recognized in the rest of the cases, while our findings of Netherlands are in accordance with Garretsen and Swank (2003) studying aggregate household loans. 
Table 3: Treating consumer credits as Endogenous vs. Exogenous variable

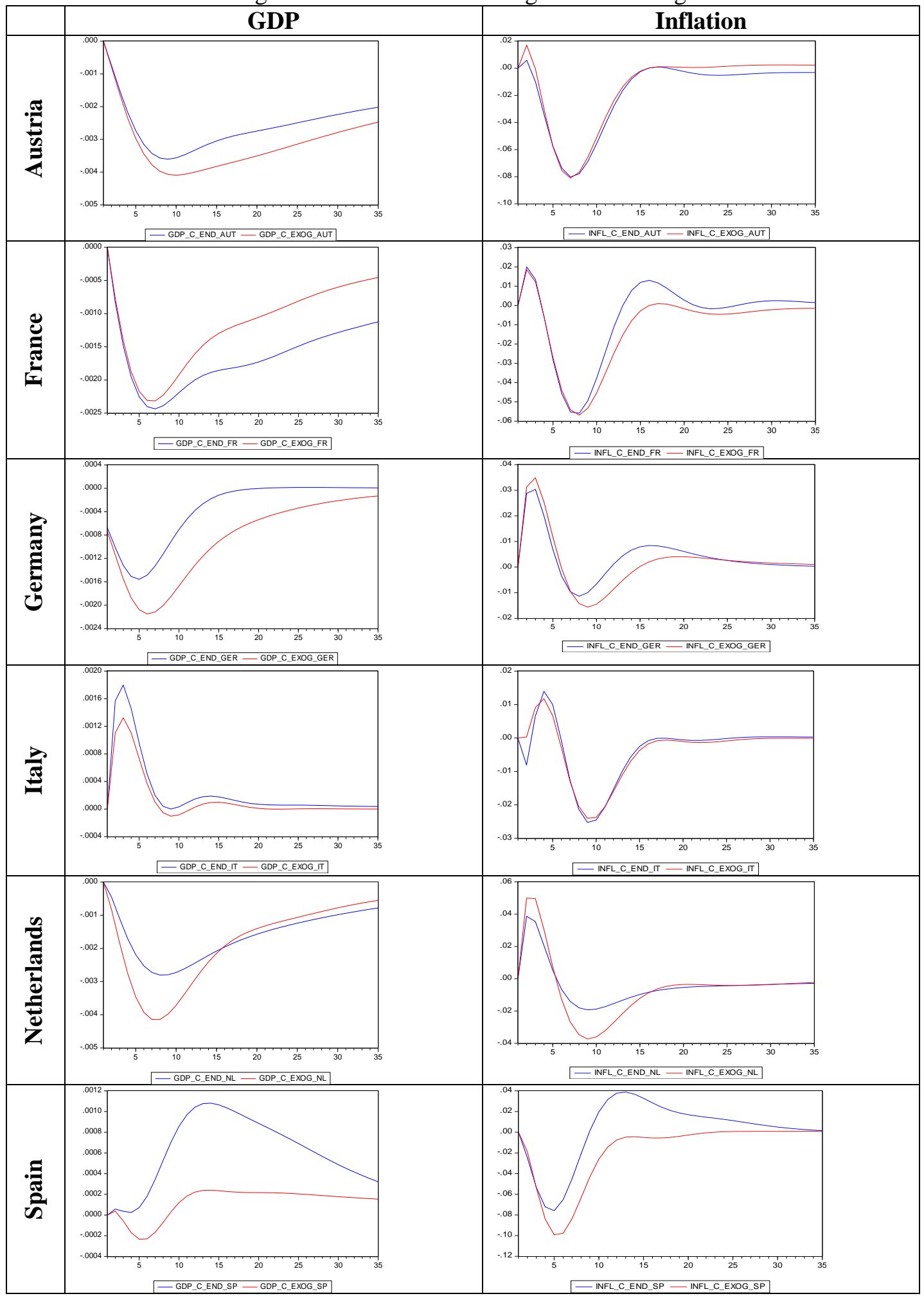


Looking at the time pattern of monetary policy transmission, two dimensions can be described. On the one hand the time it takes the impulses to reach the maximum effect, and on the other hand the time impulses to die out. Fig.2(a) and Fig.2(b) plot both dimensions on housing and consumption credit, respectively in countries where we have evidence for active relevant channels. In Fig.2(a), where we show the time pattern to housing response, we can assume that there are three groups of countries clustering. The position of Germany and UK in the lower left corner of the figure indicates that monetary transmission to housing loans proceeds quickly in these countries. In the middle of Fig.2(a) Belgium and Spain are rather homogeneous concerning housing loans responses to monetary policy shocks. On the contrary, on the upper right corner of the figure, France, Austria, Italy and Sweden have very long-lasting effects that intensify much longer than in the other countries of the figure.

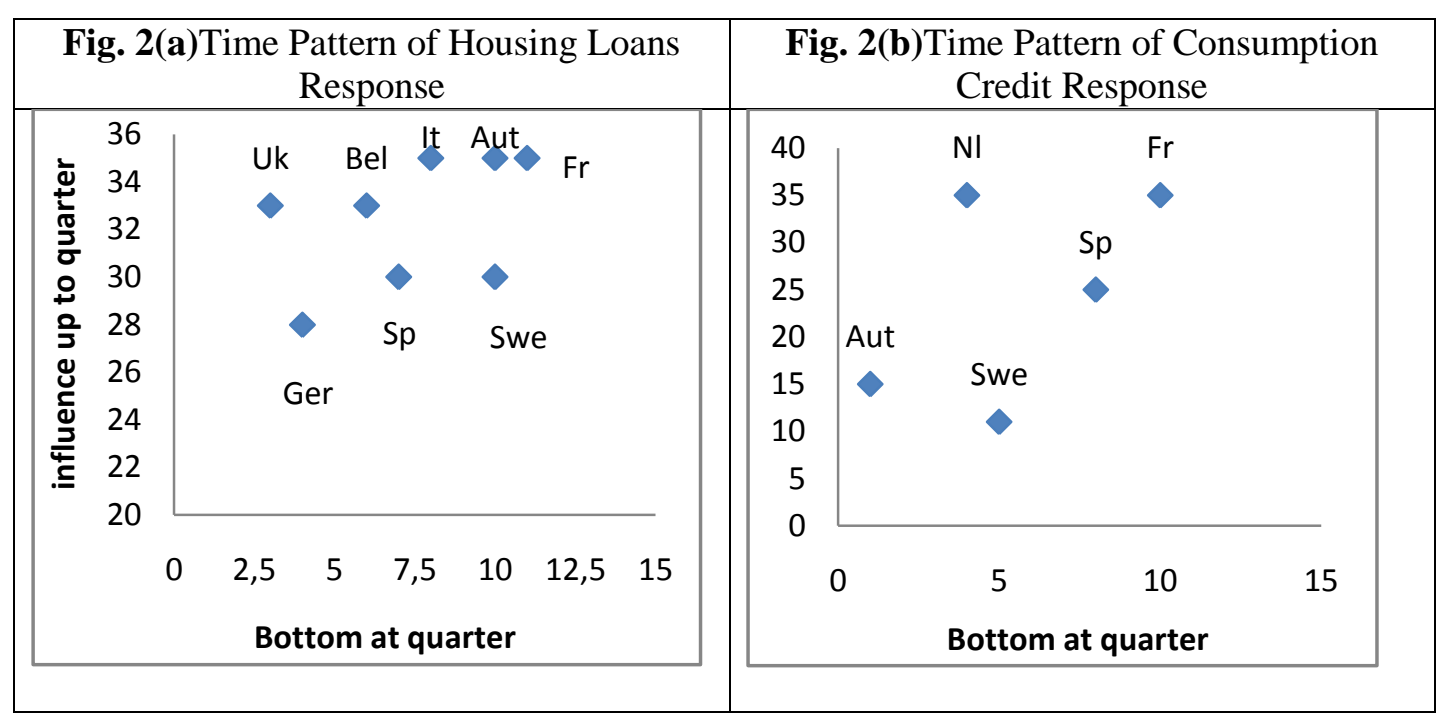

Another interesting point in Fig.2(b), that presents the consumption credit response to a monetary tightening, is the fact the negative influence dies between eleven and thirty-five quarters. The time that consumption credits reach their bottom varies but the time that impulse responses die is common.

Finally, a clear-cut result has been depicted in Fig.3(a) and Fig. 3(b), where we portray the time pattern of output and inflation responses. The time pattern of output response implies high level of concentration concerning the quarter that the effect reaches its maximum (in absolute terms) while higher variability concerning the duration of the effect. The opposite situation occurs on time of inflation response as can be seen in Fig.3(b). Inflation reaction due to monetary policy shock seems to dies between twelve and twenty-five quarters for the majority of the countries studied. 


\begin{tabular}{|cc|c||c|c|c|}
\hline \multicolumn{2}{|c|}{ Fig. 3(a)Time Pattern of GDP Response } & \multicolumn{3}{|c|}{ Fig. 3(b)Time Pattern of Inflation } \\
Response
\end{tabular}

\section{Conclusions}

This paper considers the banks' lending behavior to households after a monetary policy shock. By applying an unrestricted VAR that is common for nine European countries we generate impulse responses that properly identified monetary policy shocks without incurring puzzling evidence.

Disaggregating total household loans to their components based on the purposes of these loans may reveal useful information about monetary transmission mechanism in European countries. Especially for countries of Eurozone that share a common currency, it is particularly interesting to investigate the role of bank lending channels in the economy.

Empirical finding support the existence of an active bank lending channel for the majority of the countries studied (Germany, France, Belgium, Italy, Spain, Sweden and UK - seven out of nine). More than half of the GDP reduction due to monetary policy shock can be attributed to housing loans reductions. However, among them there are significant differences concerning time pattern responses. More specifically, the monetary transmission to housing loans proceeds quickly in Germany and UK compared to the others. Among the other countries, France has long-lasting effects that intensify much longer than in the other countries. In Spain, France, UK and Belgium there is also time lag in the response of GDP and inflation to interest rate shocks that can be explained by the housing loans reductions.

However in France, Germany and Spain, consumer credits reduction also amplifies the initial shock on GDP and inflation produced by a tightening monetary policy. Among them, Spain presents the strongest effect concerning consumer credit. Another interesting point, the time that consumption credits reach their bottom varies but the time that impulse responses die is common. 
Additionally, banks' lending behavior varies significantly according to the purposes of household loans (in line with De Haan et al., 2007). In Belgium, Sweden and UK, housing loans reductions coexist with increase of loans for consumption and other reasons, implying that the former is driven by supply forces while the latter by demand forces.

Finally, on the one hand time pattern of GDP response implies clustering for some countries concerning the time reaching the maximum effect in absolute terms, while the duration of the effect varies significantly. On the other hand, time pattern of inflation response provide evidence of homogeneity in the duration of the monetary policy effect while significant heterogeneity in the time achieved the maximum effect. The above results have useful policy implications for the monetary transmission in Europe.

ACKNOWLEDGEMENTS: We thank for comments the participants of EEFS conference (London, June 2011) on earlier version of this paper. Particularly we want to thank Professors K. Kuttner and G. Chortareas for their remarks during the conference along with Professors Hong Liu, and M. Delis for their comments for the better understanding and presentation of the subject we cope with.

\section{References}

Altavilla, C., 2000. Measuring monetary policy asymmetries across EMU, Rivista Internazionale di Scienze Sociali No.1.

Altunbas, Y., Fazylow, O. and Molyneux, P. (2002) Evidence on the bank lending channel in Europe, Journal of Banking and Finance, 26, 2093-2110.

Angeloni, I., Kashyap, A., Mojon, B. and Terlizzese, D. (2002) Monetary transmission in the euro area: where do we stand?,ECB Working Paper Series No. 114.

Aoki, K., Proudman, J. and Vlieghe, G.(2004) House prices, consumption, and monetary policy: a financial accelerator approach, Journal of Financial Intermediation, 13, 414435.

Barran, F., Coudert, V. and Mojon, B. (2003)The transmission of monetary policy in European countries CEPII, Document de travail No. 96.

Bernanke, B.(1986) Alternative explanations of the Money-Income Correlation, Carnegie Rochester Conference Series on Public Policy 25.

Bernanke, B.(1993) Credit in the macroeconomy, FRBNY Quarterly Review Spring, 5070

Bernanke, B. and Blinder, A.(1988) Credit, money, and aggregate demand, American Economic Review,78, 435-439.

Bernanke, B. and Blinder, A.(1992)The federal funds rate and the channels of monetary transmission, American Economic Review,82, 901-921.

Bernanke, B. and Gertler, M.(1995)Inside the black box: the credit channel of monetary policy transmission, Journal of Economic Perspectives,9, 27-48.

Brissimis, SN. and Magginas, NS.(2006) Forward-looking information in VAR models and the price puzzle, Journal of Monetary Economics,53, 1225-1234.

Buttigliore, L. and Ferri, G. (1994) Monetary policy transmission via lending rates in Italy: any lessons from recent experience?, Banca d' Italia, Discussion Paper No. 224.

Cecchetti, S.(1999)Legal structure, financial structure, and the monetary transmission mechanism, Federal Reserve Bank of New York Economic Policy Review, 5, 9-28. 
Christiano, L., Eichenbaum, M. and Evans, C. (1999)Monetary policy shocks: what have I learned and to what end? In: Woodford, M. and Taylor, J.B. (Eds.), Handbook of Macroeconomics. North-Holland, Amsterdam, 65-148.

Christiano, L., Eichenbaum, M. and Evans, C. (1994)The Effects of Monetary Policy Shocks: Some Evidence from the Flow of Funds, NBER Working Paper No. 4699.

Dale, S. and Haldane, G.(1995) Interest rates and the channels of monetary transmission: some sector al estimates, European Economic Review,39, 1611-1626.

De Bondt, G., Mojon, M. and Valla, N.(2003) Term structure and the sluggishness of retail bank rates in the Euro area European Central Bank, mimeo.

De Bondt, GJ.(2004)The balance sheet channel of monetary policy: first empirical evidence for the euro area corporate bond market, International Journal of Finance and Economics,9, 219-228.

Dedola, L. and Lippi, F.(2005)The monetary transmission mechanism: evidence from the industries of five OECD countries, European Economic Review,49, 1543-1569.

Den Haan, W-J., Sumner, S-W. and Yamashiro, G-M.(2007) Banks' loan portfolio and the monetary transmission mechanism, Journal of Monetary Economics, 54, 904-924.

Ehrmann, M.(2000)Comparing monetary policy transmission across European countries, Review of World Economics (WeltwirtschaftlichesArchiv),136, 58-83.

Ehrmann, M., Gambacorta, L., Martinez Pagés, J., Sevestre, P. and Worms, A. (2001) Financial Systems and the Role of Banks in Monetary Policy Transmission in the Euro Area, ECB Working Paper No. 105.

Elbourne, A. (2008) The UK housing market and the monetary policy transmission mechanism: An SVAR approach, Journal of Housing Economics, 17, 65-87.

Escriva, J. and Haldane, G. (1994) The interest rate transmission mechanism: Sectoral estimates for Spain Banco de Espana, Discussin Paper No. 9414.

Favero, C.(2001) Applied Macroeconometrics, Oxford University Press, Oxford, UK.

Favero, C., Giavazzi, F., Flabbi, L. and (1999)The Transmission Mechanism of Monetary Policy in Europe: Evidence from Banks' Balance Sheets, NBER Working Paper Series No. 7231.

Fischer, B., Lenza, M., Pill, H. and Reichlin, L. (2009)Monetary analysis and monetary policy in the euro area 1999-2006, Journal of International Money and Finance,28, 1138-1164.

Friedman, B. and Kuttner, K.(1992) Money, Income, Prices and Interest Rates, American Economic Review, 82, 472-492.

Gambacorta, L.(2005) Inside the bank lending channel, European Economic Review,49, 1737-1759.

Garretsen, H. and Swank, J.(1998) The transmission of interest rate changes and the role of bank balance sheets: a VAR-analysis for the Netherlands, Journal of Macroeconomics, 20, 325-339.

Garretsen, H. and Swank, J.(2003) The bank lending channel in the Netherlands: the impact of monetary policy on households and firms, De Economist,151, 35-51.

Gerlach, F. and Smets, F.(1995)The monetary transmission mechanism: evidence from the G7 countries, CEPR Discussion Paper, 1219.

Gertler, M. and Gilchrist, S.(1993a)The role of credit market imperfections in the monetary transmission mechanism: arguments and evidence, The Scandinavian Journal of Economics, 95, 43-64. 
Gertler, M. and Gilchrist, S.(1993b)The cyclical behavior of short-term business lending: implications for financial propagation mechanisms, European Economic Review,37, 623-631.

Giuliodori, M.(2005)The role of house prices in the monetary transmission mechanism across European countries, Scottish Journal of Political Economy,52, 519-543.

Guende, A. andMoersch, M.(1997) On the existence of a credit channel of monetary policy in Germany, Kredit und Kapital, 30, 173-185.

Hernando, I. and Pagés, J-M.(2001) Is there a bank lending channel of monetary policy in Spain?,ECB Working Paper Series No. 99.

Huang, Z.(2003) Evidence of a bank lending channel in the UK, Journal of Banking \& Finance, 27, 491-510.

Iacoviello, M. (2004) Consumption, house prices, and collateral constraints: a structural econometric analysis, Journal of Housing Economics, 13, 304-320.

Iacoviello, M. and Minetti, R.(2008) The credit channel of monetary policy: evidence from the housing market, Journal of Macroeconomics,30, 69-96.

Kakes, J., Sturm, J-E. and Maier, P. (1999)Monetary transmission and bank lending in Germany, CCSO Working Paper No.199906.

Kashyap, A., Rajan, R. and Stein, J. (2002) Banks as liquidity providers: An explanation for the coexistence of lending and deposit-taking, The Journal of Finance, 57, 33-73.

Kashyap, A. and Stein, J.(1995) The impact of monetary policy on bank balance sheets, Carnegie Rochester Series on Public Policy.

Kashyap, A. and Stein, J.(1997)The role of banks in monetary policy: A survey with implications for the European monetary union, Economic Perspectives, 21, 2-18.

Kashyap, A. and Stein, J.(2000) What do a million observations on banks say about the transmission of monetary policy?, American Economic Review,90, 407-428.

Kieler, M. and Saarenheimo, T.(1998) Differences in monetary policy transmission? A case not closed, European Commission, Economic Papers No. 132.

Kishan, R. and Opiela, T.(2000) Bank size, bank capital and the bank lending channel, Journal of Money, Credit, and Banking,32, 121-141.

Koufmann, S. and Valderrama, M-T.(2008) Bank lending in Germany and the UK: are there differences between a bank-based and a market-based country? International Journal of finance and economics,13, 266-279.

Kuppers, M. (2001) Curtailing the black box: German banking groups in the transmission of monetary policy, European Economic Review,45, 1907-1931.

Leung, C. (2004) Macroeconomics and housing: a review of the literature, Journal of Housing Economics, 13, 249-267.

Maclennan, D., Muellbauer, J. and Stephens, M. (1998) Asymmetries in housing and financial institutions and EMU, Oxford Review of Economic Policy, 14, 54-80.

McCarthy, J. and Peach, R-W.(2002)Monetary policy transmission to residential investment, FRBNY Economic Policy Review, 8, 139-158.

Mishkin, F.(2001)The transmission mechanism and the role of asset prices in monetary policy, NBER Working Paper Series No. 8617.

Mojon, B.(2000)Financial structure and the interest rate channel of ECB monetary policy, ECB Working Paper Series No. 40.

Mojon, B. and Peersman, G.(2001) A VAR description of the effects of monetary policy in countries of the Euroarea, ECB Working Paper Series No. 92. 
Morsink, J. and Bayoumi, T.(2001) A Peek Inside the Black Box: The Monetary Transmission Mechanism in Japan, IMF Staff Papers, Palgrave Macmillan Journals, 48, 22-57.

Muellbauer, J. and Murphy, A.(1997) Booms and busts in the UK housing market, The Economic Journal,107, 1701-1727.

Papadamou, S. (2013).Market anticipation of monetary policy actions and interest rate transmission to US Treasury market rates. Economic Modelling, 33, 545-551.

Papadamou, S. and Siriopoulos, C. (2012) Banks' lending behavior and monetary policy: evidence from Sweden, Review of Quantitative Finance and Accounting,38, 131-148.

Papadamou, S., Sidiropoulos, M., \& Spyromitros, E. (2014a) Central Bank Transparency and the Interest Rate Channel: Evidence from Emerging Economies, Economic Modelling, 10.1016/j.econmod.2014.10.016.

Papadamou, S., Sidiropoulos, M., \& Spyromitros, E. (2014b). Central bank credibility aspects and macroeconomic performance: Evidence from Eastern European and Latin American countries, Eastern European Economics, forthcoming May.

Peek, J. and Rosengren, E.(1995) Bank lending and the transmission of monetary policy. In Peek J, Rosengren E (eds.), Is bank lending important for the transmission of monetary policy?, Conference Series 39, 47-68, Federal Reserve Bank of Boston.

Peersman, G.(2004) The Transmission of Monetary Policy in the Euro Area: Are the Effects Different Across Countries?, Oxford Bulletin of Economics and Statistics,66, 285-308.

Peersman, G. and Smets, F.(2003)The monetary transmission mechanism in the euro area: evidence from VAR analysis, in Monetary Policy Transmission in the Euro Area: I. Angeloni, A.K. Kashyap and B. Mojon, Cambridge University Press, pp. 36-55.

Ramaswamy, R. and Sloek, T.(1998)The real effects of monetary policy in the European Union: what are the differences, IMF Staff Papers, 45, 374-396.

Ramey, V.(1993) How important is the credit channel in the transmission of monetary policy?, Carnegie-Rochester Conference Series on Public Policy,39, 1-45.

Sims, C.(1980) Macroeconomics and reality, Econometrica,48, 1-48.

Sims, C., Stock, J. and Watson, M.(1990) Inference in linear time series models with some unit roots, Econometrica,58, 113-144.

Stein, J.(1998)An adverse selection model of bank asset and liability management with implications for the transmission of monetary policy, RAND Journal of Economics,29, 466-486.

Toolsema, L.(2002) Competition in the Dutch consumer credit market, Journal of Banking \& Finance,26, 2215-2229.

Tsatsaronis, C.(1995) Is there a Credit Channel in the Transmission of Monetary Policy? Evidence from Four Countries, in BIS, Financial Structure and the Monetary Policy Transmission Mechanism, CB document 394, pp. 154-187.

Warnock, V.C. and Warnock, F.E. (2008) Markets and housing finance, Journal of Housing Economics, 17, 239-251.

Weber, A., Gerke, R. and Worms, A. (2009) Has the monetary transmission process in the euro area changed? Evidence based on VAR estimates, Working Papers No. 276, Bank for International Settlements.

Yao, R. and Zhang, H-H.(2005) Optimal Consumption and Portfolio Choices with Risky Housing and Borrowing Constraints, Review of Financial Studies,18, 197-239. 